\title{
EVALUATION OF VITAMIN D STATUS AMONG THE DOCTORS OF BANGLADESH - A MULTI-CENTER CROSS-SECTIONAL STUDY
}

\author{
QUAZI TARIKUL ISLAM ${ }^{1}$, MD. ALIMUR REZA² MD. KHALILUR RAHMAN ${ }^{3}$, A. F. M. NAZMUL ISLAM ${ }^{4}$, \\ SAIYEEDUR RAHMAN ${ }^{5}$, SATYA RANJAN SUTRADHAR ${ }^{6}$, DEVENDRA NATH SARKAR ${ }^{7}$, MD. ZAKIR HOSSAIN $^{8}$, \\ ASHOK KUMAR DUTTA ${ }^{9}$, S M KAMAL $^{10}$, RIYADH MOTALEB ${ }^{11}$
}

\begin{abstract}
Introduction: Vitamin D deficiency has been linked to a whole spectrum of diseases including osteoporosis, cancer, diabetes, and cardiovascular and immune disorders. Though Bangladesh is low latitude country, vitamin D Deficiency is serious and wide spread problem in Bangladesh. Physicians of Bangladesh are more vulnerable to low vitamin D status due to long indoor work hours and lack of sunlight exposure in both government \& private institute. So, the aim of this study to evaluate vitamin D status among the physicians working around the Bangladesh.
\end{abstract}

Methods: This was a cross-sectional, multicenter study where we enrolled 1112 doctors from 9 different areas of Bangladesh from May 2018 to June 2019. A Blood sample was collected from all participants to measure Serum 25(OH)D and various patient data such as age, gender, BMI, physical activity level during leisure time, use of vitamins and medications, sunlight exposure time, tea/coffee drinking, smoking, $\mathrm{H} / \mathrm{O}$ comorbidities etc. was collected.

Results: Of the 1112 doctors assessed in the study, 794 (71.4\%) was male and 318 (28.6\%) was female. Mean age of the participants was 45.5 \pm 11 .1 Years. Vitamin D deficiency and insufficiency was found in 734 (65.8\%) and 105 (9.4\%) participants respectively. Mean vitamin D level was 18.9 $\mathrm{ng} / \mathrm{ml}( \pm 8.6 \mathrm{ng} / \mathrm{ml})$. Less than $5 \%$ of participants of Rajshahi, Rangpur, Dhaka, Bogura and Sylhet had sufficient vitamin D level. Vitamin D deficiency was significantly associated with age, obesity, sunlight exposure, physical inactivity, hypertension and vitamin D supplementation.

Conclusion: Vitamin D deficiency is very common among physicians of all over Bangladesh. The high prevalence of vitamin D deficiency in the present study points towards urgent need of an integrated approach to detect vitamin D deficiency among health care professionals and treat appropriately.

Received: 29 October, 2020

Accepted: 25 December, 2020

DOI: https://doi.org/10.3329/bjm.v32i1.51092

\section{Introduction}

Vitamin D deficiency is pandemic, yet it is the most under-diagnosed and under-treated nutritional deficiency in the world ${ }^{1-3}$. Vitamin D deficiency is widespread in individuals irrespective of their age, gender, race and geography. Vitamin $\mathrm{D}$ is photo- synthesized in the skin on exposure to UVB rays. Sun exposure alone ought to suffice for vitamin $D$ sufficiency. However, vitamin D deficiency is widely prevalent despite plentiful sunshine even in tropical countries like Bangladesh.

1. Professor of Medicine, Popular Medical College \& Hospital

2. Manager, Medical Affairs, Beximco Pharmaceuticals Ltd

3. Professor \& Dept. Head of Medicine, Rajshahi Medical College \& Hospital

4. Former Professor \& Dept. Head of Medicine, M.A.G. Osmani Medical College \& Hospital

5. Former Professor \& Dept. Head of Medicine, Sher-E-Bangla Medical College \& Hospital

6. Former Professor \& Dept. Head of Medicine, Mymensingh Medical College \& Hospital

7. Professor \& Dept. Head of Medicine, Rangpur Medical College \& Hospital

8. Professor \& Dept. Head of Medicine, Shaheed Ziaur Rahman Medical College \& Hospital

9. Former Professor \& Dept. Head of Medicine, Chittagong Medical College Hospital

10. Professor \& Dept. Head of Medicine, Khulna Medical College Hospital

11. Senior Executive, DMA, Beximco Pharmaceuticals Ltd

Address of correspondence: Professor Quazi Tarikul Islam, Professor of Medicine, Popular Medical College Hospital, Dhaka. Email: prof.tarik@gmail.com

Bangladesh J Medicine 2021; 32 : 31-38 
It has been estimated that $20 \%$ to $80 \%$ of US, Canadian, and European men and women are vitamin D deficient. ${ }^{4,5}$ The prevalence of serum 25(OH)D levels less than $20 \mathrm{ng} / \mathrm{mL}$ was almost one-third of the US population (32\%). In a national Canadian cohort, serum 25(OH)D levels less than $30 \mathrm{ng} / \mathrm{mL}$ were evident in $57.5 \%$ of men and in $60.7 \%$ of women, and they rose to $73.5 \%$ in spring (men) and $77.5 \%$ in winter (women) ${ }^{5}$. In the Healthy Lifestyle in Europe by Nutrition in Adolescence study, 25(OH)D levels less than $30 \mathrm{ng} / \mathrm{mL}$ were reported to be approximately $80 \%$ in adolescents from the 9 European countries. ${ }^{6}$ In a study on the vitamin D status of Australian adults, vitamin D deficiency (25[OH]D $<20 \mathrm{ng} / \mathrm{mL}$ ) was $31 \%$ ( $22 \%$ in men and $39 \%$ in women); $73 \%$ had $25(\mathrm{OH}) \mathrm{D}$ levels less than $30 \mathrm{ng} / \mathrm{mL} .{ }^{7}$ In the Middle East and Asia, vitamin D deficiency in children and adults is highly prevalent. ${ }^{8,9}$ In South Asia, $80 \%$ of the apparently healthy population is deficient in vitamin $\mathrm{D}(<20 \mathrm{ng} / \mathrm{mL})$ and up to $40 \%$ of the population is severely deficient $(<9 \mathrm{ng} / \mathrm{mL})^{10}$. In Bangladesh, a prevalence study was done on women and found that hypovitaminosis $\mathrm{D}$ is common in women regardless of age, lifestyle and clothing ${ }^{11}$. Prevalence of hypovitaminosis defined as $25(\mathrm{OH}) \mathrm{D}$ levels below $37.5 \mathrm{nmol} / \mathrm{L}$ was $38 \%$ in Bangladeshi women from high income group and increased slightly to $50 \%$ in women from low income groups ${ }^{12}$.

The classical actions of vitamin D include the regulation of mineral ion homeostasis and bone metabolism. Therefore, vitamin $\mathrm{D}$ has been associated primarily with bone health, and it is well known that vitamin D can reduce bone resorption and subsequent bone loss. Prior studies in adults suggested that vitamin D increased bone mineral density (BMD) ${ }^{13}$, which in turn associated with decreased osteoporotic fractures ${ }^{14}$, and better musculoskeletal function in the lowerextremities of the elderly ${ }^{15}$.

More recently, nonclassical actions of vitamin D have been recognized, e.g. control of cell growth and differentiation, regulation of immune function and endocrine effects, such as insulin resistance, inflammation, renal and muscle function ${ }^{18}$. Vitamin $\mathrm{D}$ receptor (VDR), which triggers most of vitamin D actions, is widely distributed across almost all the major human organs including heart, brain, livers, bone, kidney, and urinary system, as well as a number of tissues such as immune cells, pancreatic beta cells, cardiomyocytes, endothelial cells, and vascular smooth cells. Through the widely distributed VDR, vitamin D controls vital genes related to bone metabolism, oxidative damage, inflammation, and chronic diseases ${ }^{19}$. Therefore, vitamin $\mathrm{D}$ deficiency has been linked to a wide spectrum of diseases including osteoporosis, cancer, diabetes, and cardiovascular and immune disorders ${ }^{20}$. Evolving data indicated that vitamin $\mathrm{D}$ was capable to influence pancreatic betacell proliferation and survival; and hence impaired vitamin D status was associated with higher prevalence and incidence of diabetes ${ }^{21}$. Several previous studies have shown that lower vitamin D status was associated with increased fasting blood glucose (FBG) levels. ${ }^{22,23}$ Additionally, adequate vitamin $\mathrm{D}$ status is important for optimal function of cardiovascular system. It has been reported that vitamin D deficiency caused an increase in parathyroid hormone (PTH), which increased insulin resistance and was associated with diabetes, hypertension, inflammation, and increased cardiovascular risks ${ }^{25}$. Epidemiological studies have associated with vitamin D deficiency and coronary risk factors with adverse cardiovascular outcomes. The strong association between vitamin $\mathrm{D}$ status and cardiometabolic health may contribute to the higher risk of all-cause mortality in vitamin $D$ deficient individuals ${ }^{26}$.

Therefore, vitamin D deficiency has been linked to a whole spectrum of diseases including osteoporosis, cancer, diabetes, and cardiovascular and immune disorders. Though Bangladesh is low latitude country, but for some other various factors such as religious belief, socio-economic upgradation, atmospheric pollution, clothing style, vitamin D Deficiency is serious and widespread problem in Bangladesh. Physicians of Bangladesh are more vulnerable to low vitamin D status due to long indoor work hours and lack of sunlight exposure in both government \& private institute. So, the aim of this study to evaluate vitamin D status among the physicians working around the Bangladesh.

\section{Materials \& Method}

Overall design and eligibility criteria

This was a multi-center, cross sectional study which was conducted in 9 different cities of Bangladesh during the period of May, 2018 to June, 2019. We purposely selected the study area in eight different administrative division of Bangladesh according to the location, number of doctors and location of medical college etc. The study was approved by the ethics committee of Popular Medical College \& Hospital in Dhaka. In this study we enrolled 1112 doctors from Dhaka, Chattogram, Sylhet, Rajshahi, Bogura, Rangpur, Barishal, Khulna and Mymensingh districts. In each area we selected both specialist and general physicians for the study. Healthy male and female doctors in those area who were willing to take part was included in the study. Participants were excluded if they were pregnant or diagnosed with any hepatic 
or renal disease, metabolic bone disease, malabsorption, type 1 diabetes, hypercortisolism, malignancy etc and who were immobile for more than one week. Participants using medications affecting either vitamin $\mathrm{D}$ absorption or bone health were also excluded. This study was conducted according to the guidelines laid down in the Declaration of Helsinki.

\section{Data Collection Procedure}

Data collection was conducted in a predefined examination centers at each area by trained research assistant according to a standard protocol. All subjects were physically examined and interviewed using a standardized questionnaire to collect information on age, gender, physical activity level during leisure time, use of vitamins and medications, sunlight exposure time, coffee drinking (yes/no), smoking, self-reported diabetes, self-reported coronary heart disease (CHD), and self-reported stroke. The smoking habit was classified as never, current (smoking regularly in the past 6 months), or ever (cessation of smoking for more than 6 months), Subjects were divided into two groups based on tea/coffee consumption: group I, Less than 14 cups of tea/coffee weekly; group II, more than 14 cups of tea/coffee weekly. Daily sunlight exposure was quantified based on the interview questions on frequency and length of outdoor activities, sunscreen use, and usual outdoor attire. Body weight and height were measured according to a standard protocol, and body mass index (BMI) was calculated as weight in kilograms divided by height in meters squared. Weight was defined as normal weight (BMI d"24.0 kg/m2), overweight (BMI e"24.0 to $28.0 \mathrm{~kg} / \mathrm{m} 2$ ) or obese (BMI e"28.0 kg/m2). Blood pressure was measured in the non-dominant arm while the participants were in a seated position after 5 min of rest using a sphygmomanometer device. Hypertension was defined as a sitting blood pressure of at least $140 \mathrm{~mm} \mathrm{Hg}$ systolic or $90 \mathrm{~mm} \mathrm{Hg}$ diastolic or history of antihypertensive drug use.

\section{Biochemical analysis}

A Blood sample was collected from all participants and centrifuged within 30 mins of collection. Serum samples were kept frozen until analysis. Serum 25hydroxyvitamin D [25(OH)D] concentrations was measured by chemiluminescence immunoassay (CLIA). The measuring range for $25(\mathrm{OH}) \mathrm{D}$ will be $4-100 \mathrm{ng} /$ mL. TG, CHOL, LDL-C, and HDL-C levels was measured enzymatically on an automatic analyzer. Plasma glucose was measured locally using glucose oxidase methods. Levels of HbA1c was also measured by high-performance liquid chromatography (HPLC), with a within run coefficient of variation of 0.78 . Serum 25-OHD was used to evaluate the vitamin D status. According to US Endocrine society guideline, vitamin $\mathrm{D}$ deficiency was defined as a serum circulating 25hydroxyvitamin D [25(OH)D] level below $20 \mathrm{ng} / \mathrm{ml}$ (50 $\mathrm{nmol} /$ liter), and vitamin D insufficiency as a $25(\mathrm{OH}) \mathrm{D}$ of 21-29 $\mathrm{ng} / \mathrm{ml}$ (52.5-72.5 nmol/liter).

\section{Statistical analysis}

Descriptive analysis was carried out on the study variables and the frequency table of determinants and socio-demographic characteristics were created. Data was shown as mean \pm SD and prevalence rates was reported as percentages and $95 \%$ confidence intervals. The differences were considered significant at $p$ values of less than 0.05. With respect to the participants' vitamin $\mathrm{D}$ status and characteristics, t-test for independent samples and one-way ANOVA were used for continuous data, and the Chi-square test was used to compare frequencies. All analyses were performed using SPSS for Windows, version 17.0 (SPSS Inc., Chicago, IL, USA).

\section{Results:}

Of the 1112 doctors assessed in the study,794 (71.4\%) was male and 318 (28.6\%) was female. Mean age of the participants was $45.5 \pm 11.1$ Years. Among them $204(18.3 \%)$ participants age was less than 30 years, and almost two-third of participants age was 31-59 years and only $158(14.2 \%)$ participants age was more than 60 years or more. Only one-third participants have normal BMI, whereas two-third participants have either overweight or obesity. Total 893 (80.5\%) participants had no history of smoking and half of them took more than 2 cups coffee/tea every day. Of all participants, 296 (27\%) had a history of more than 30 minutes/day exercise. In 229 (20.6\%) participants exposure to sunlight is sufficient whereas 880 (79.4\%) participants was insufficient. Among them, 332 (30\%) participants had history of hypertension, 190 (17\%) had Diabetes, 172 (15\%) had Dyslipidemia, 68 (6\%) had established cardiovascular disease (e.g. MI, Angina etc.) and $11(0.99 \%)$ participants had history of stroke (Table 1).

Estimated level of vitamin D level was categorized as deficient $(<20 \mathrm{ng} / \mathrm{ml})$ and insufficient $(21-29 \mathrm{ng} / \mathrm{ml})$ and sufficient (>30 $\mathrm{ng} / \mathrm{ml}$ ). Mean vitamin D level was $18.9 \mathrm{ng} / \mathrm{ml}$ with standard deviation $8.6 \mathrm{ng} / \mathrm{ml}$. Minimum vitamin D level was found $4.58 \mathrm{ng} / \mathrm{ml}$ and maximum $99.7 \mathrm{ng} / \mathrm{ml}$. Vitamin D deficiency was found 734 (65.8\%) participants whereas Vitamin D sufficiency 
was found in 277 (24.8\%) participants and Vitamin D insufficiency was found in 105 (9.4\%) participants (Figure 1). Among all 09 districts, highest mean Vitamin D concentration was found in Mymensingh (26.3 ng/ $\mathrm{ml}$ ) and lowest mean in Rajshahi (13.2 ng/ml).

Among all districts, around three-fourth of the participants had deficiency in Rajshahi (90.7\%), Rangpur (83.0\%), Bogura (77.1\%), Dhaka (76.3\%) and Sylhet $(74.8 \%)$. Less than half of the participants had deficiency in Khulna (36.4\%) and Mymensingh (19.2\%).

On the other hand, less than $5 \%$ of the participants had sufficient vitamin D level in Rajshahi (2.9\%), Rangpur (3.4\%), Dhaka (3.8\%), Bogura (4.2\%) and Sylhet (4.9\%) and more than 20\% in Mymensingh (27.9\%), Khulna (21.5\%) and Chittagong (20.2\%). Of all participants, $253(22.8 \%)$ had history of Vitamin D supplementation and 859 (77.2\%) had no history.

Table-I

Vitamin D status of all participants in respect to different variables $(n=1112)$

\begin{tabular}{|c|c|c|c|c|c|}
\hline \multirow{2}{*}{ Variables } & \multirow{2}{*}{$\begin{array}{c}\text { Frequency } \\
\mathrm{N}(\%)\end{array}$} & \multicolumn{2}{|c|}{ Serum D3 concentration (ng/dl) } & \multicolumn{2}{|c|}{ Vitamin D Deficiency } \\
\hline & & Mean $\pm \mathrm{SD}$ & P-value & $\%$ & P-value \\
\hline \multicolumn{6}{|l|}{ Age (Years) } \\
\hline$<35$ years & 204 (18.3\%) & $17.37 \pm 7.01$ & 0.000 & $70.60 \%$ & 0.003 \\
\hline $36-45$ years & 376 (33.8\%) & $17.75 \pm 7.33$ & & $71.00 \%$ & \\
\hline 46-59 years & 374 (33.6\%) & $19.63 \pm 8.57$ & & $62.60 \%$ & \\
\hline$>60$ years & $158(14.2 \%)$ & $21.74 \pm 12.07$ & & $55.10 \%$ & \\
\hline \multicolumn{6}{|l|}{ Gender } \\
\hline Male & $794(71.4 \%)$ & $18.85 \pm 8.02$ & 0.804 & $66.50 \%$ & 0.105 \\
\hline Female & $318(28.6 \%)$ & $18.99 \pm 10.01$ & & $64.20 \%$ & \\
\hline \multicolumn{6}{|l|}{ BMI } \\
\hline Underweight & $2(0.2 \%)$ & $32.75 \pm 1.92$ & 0.005 & $0.00 \%$ & 0.000 \\
\hline Normal & $364(32.9 \%)$ & $19.01 \pm 8.9$ & & $67.00 \%$ & \\
\hline Overweight & $563(51 \%)$ & $19.3 \pm 8.81$ & & $63.40 \%$ & \\
\hline Obesity & $176(15.9 \%)$ & $17.27 \pm 7.24$ & & $71.00 \%$ & \\
\hline \multicolumn{6}{|l|}{ Smoking } \\
\hline Never & 893 (80.5\%) & $19.03 \pm 8.47$ & 0.395 & $64.80 \%$ & 0.260 \\
\hline Current & 126 (11.4\%) & $17.91 \pm 9.36$ & & $73.00 \%$ & \\
\hline Ever & $91(8.2 \%)$ & $18.97 \pm 9.19$ & & $64.80 \%$ & \\
\hline \multicolumn{6}{|l|}{ Tea/Coffee Drinking } \\
\hline$<14$ Cups/Week & $584(53 \%)$ & $18.52 \pm 8.27$ & 0.123 & $66.80 \%$ & 0.718 \\
\hline >14 Cups/Week & $525(47 \%)$ & $19.32 \pm 9.02$ & & $64.60 \%$ & \\
\hline \multicolumn{6}{|l|}{ Physical Activity } \\
\hline Exercise $>30$ mins/day & $296(27 \%)$ & $19.7 \pm 9.4$ & 0.061 & $63.90 \%$ & 0.007 \\
\hline Exercise $<30$ mins/day & $813(73 \%)$ & $18.6 \pm 8.33$ & & $66.40 \%$ & \\
\hline \multicolumn{6}{|l|}{ Daily Sunlight Exposure } \\
\hline Sufficient & 229 (20.6\%) & $21.18 \pm 7.92$ & 0.000 & $46.50 \%$ & 0.000 \\
\hline Not Sufficient & 880 (79.4\%) & $18.29 \pm 8.72$ & & $71.00 \%$ & \\
\hline
\end{tabular}


Table-II

Vitamin D status of subjects in various areas of Bangladesh

\begin{tabular}{lcccccc}
\hline City & $\begin{array}{c}\text { Sample } \\
\text { Size (n) }\end{array}$ & $\begin{array}{c}\text { Serum } \\
\text { 25(OH)D } \\
(\text { Mean } \pm \text { SD) }\end{array}$ & $\begin{array}{c}\text { Median } \\
\text { Serum } \\
25(\mathrm{OH}) \mathrm{D}\end{array}$ & $\begin{array}{c}\text { Vitamin D } \\
\text { Deficiency } \\
\mathrm{n}(\%)\end{array}$ & $\begin{array}{c}\text { Vitamin D } \\
\text { Insufficiencyn } \\
(\%)\end{array}$ & $\begin{array}{c}\text { Vitamin D } \\
\text { Sufficiency } \\
\mathrm{n}(\%)\end{array}$ \\
\hline Barishal & 106 & $20.3 \pm 5.7$ & 19.3 & $61(57.5 \%)$ & $38(35.8 \%)$ & $7(6.6 \%)$ \\
Bogura & 144 & $16.7 \pm 6.8$ & 15.7 & $111(77.1 \%)$ & $27(18.8 \%)$ & $6(4.2 \%)$ \\
Chittagong & 94 & $23.7 \pm 10.8$ & 20.5 & $47(50.0 \%)$ & $28(29.8 \%)$ & $19(20.2 \%)$ \\
Dhaka GP & 36 & $17.2 \pm 5.1$ & 16.4 & $29(80.6 \%)$ & $6(16.7 \%)$ & $1(2.8 \%)$ \\
Khulna & 105 & $24.4 \pm 9.8$ & 22.7 & $39(36.4 \%)$ & $45(42.1 \%)$ & $23(21.5 \%)$ \\
Mymensingh & 104 & $26.3 \pm 6.8$ & 25.1 & $20(19.2 \%)$ & $55(52.9 \%)$ & $29(27.9 \%)$ \\
Rajshahi & 140 & $13.2 \pm 6.9$ & 11.4 & $127(90.7 \%)$ & $9(6.4 \%)$ & $4(2.9 \%)$ \\
Sylhet & 143 & $17.6 \pm 5.7$ & 16.5 & $107(74.8 \%)$ & $29(20.3 \%)$ & $7(4.9 \%)$ \\
Rangpur & 147 & $15.3 \pm 6.1$ & 13.8 & $122(83.0 \%)$ & $20(13.6 \%)$ & $5(3.4 \%)$ \\
Dhaka & 95 & $17.9 \pm 10.9$ & 15.9 & $71(74.7 \%)$ & $20(21.1 \%)$ & $4(4.2 \%)$ \\
\hline Total & 1112 & $18.9 \pm 8.6$ & 17.2 & $734(65.8 \%)$ & $277(24.8 \%)$ & $105(9.4 \%)$ \\
\hline
\end{tabular}

Table-III

Vitamin D Status according to H/O Supplementation

\begin{tabular}{lcccc}
\hline $\begin{array}{l}\text { H/O of Vitamin D } \\
\text { Supplementation }\end{array}$ & $\begin{array}{c}\text { Vitamin D } \\
\text { Deficiency } \\
\mathrm{n}(\%)\end{array}$ & $\begin{array}{c}\text { Vitamin D } \\
\text { Insufficiency } \\
\mathrm{n}(\%)\end{array}$ & $\begin{array}{c}\text { Vitamin D } \\
\text { Sufficiency } \\
\mathrm{n}(\%)\end{array}$ & $\begin{array}{c}\text { P- } \\
\text { Value }\end{array}$ \\
\hline Yes & $106(41.9 \%)$ & $89(35.2 \%)$ & $58(22.9 \%)$ & 0.000 \\
No & $627(73 \%)$ & $187(21.8 \%)$ & $45(5.2 \%)$ & \\
\hline
\end{tabular}

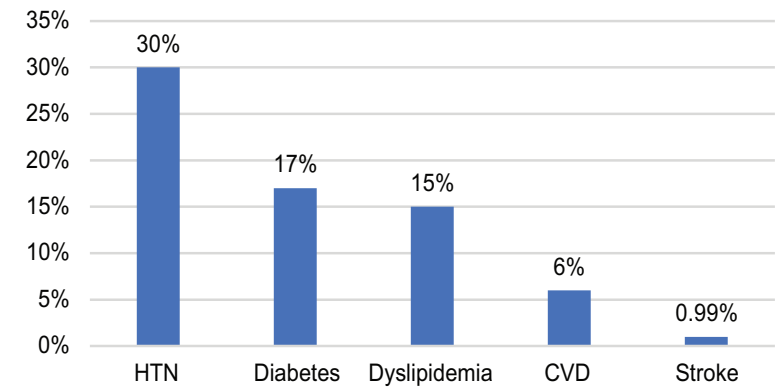

Fig.-1: Comorbidities of the participants $(n=1112)$

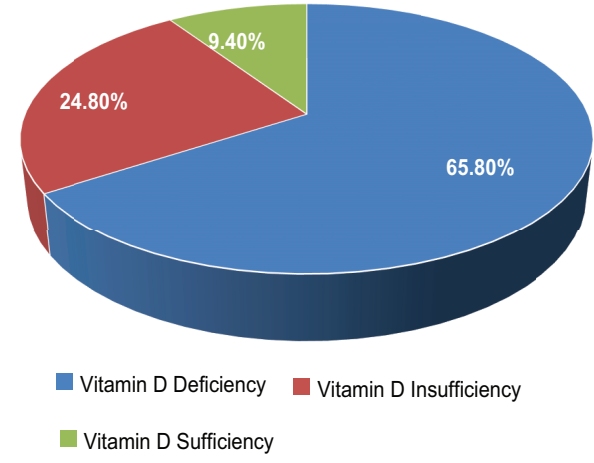

Fig.-2: Vitamin D Status of the participants $(n=1112)$

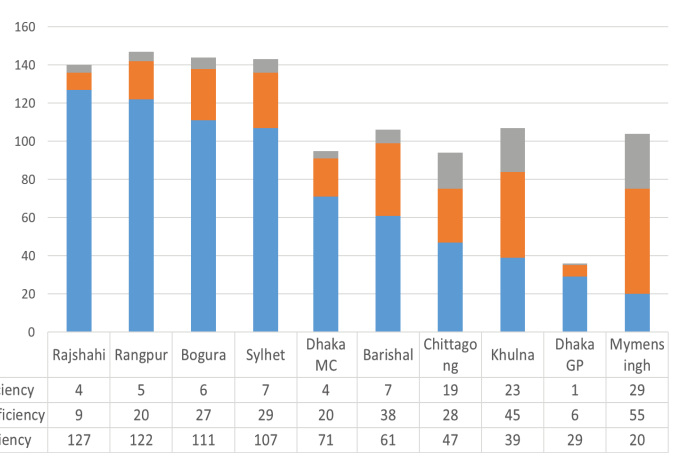

Fig.-3: Vitamin D status of subjects in various areas of Bangladesh

\section{Discussion}

It is assumed that populations living in sunny weather like Bangladesh would be less likely to be vitamin D deficient because of abundant sunshine throughout the year. However, the results of the present study challenge this assumption. The present study clearly demonstrated that vitamin $\mathrm{D}$ deficiency was common among the doctors of Bangladesh. In our study we found that almost two-thirds of the doctors of 
Bangladesh has Vitamin D deficiency and less than $10 \%$ of them had sufficient Vitamin D. Although it is reasonable to assume that the main risk factor for vitamin D deficiency (limited sun exposure) exists among the doctors as they usually work indoor. But, a previous study in Dhaka found even higher prevalence of vitamin D deficiency (89.8\%) and insufficiency (8.3\%) among the doctors of National Institute of Traumatology and Orthopedic Rehabilitation of Bangladesh ${ }^{29}$. Higher prevalence was also found in a study with young resident doctors (95\%) in North India ${ }^{30}$, health care professionals in Qatar $(87 \%)^{31}$, medical students in Saudi Arabia $(96 \%)^{32}$. Several similar findings also shown in different studies like medical students and residents at an urban university hospital in USA (67\%)33, among physicians in Jerusalem $(68 \%)^{34}$ and among resident physicians $(57.4 \%)$ of a general hospital in southern Brazil ${ }^{35}$.

An interesting finding was that the vitamin D levels were higher among older physicians in our study populations as compared to younger physicians. Since there are no studies in the literature describing increases in vitamin D levels with age, it is unlikely that the age difference contributes to the lower vitamin $\mathrm{D}$ among physicians. In our sample, gender was not associated with higher serum 25(OH)D levels. This finding differs from previous population-based studies that have noted higher serum $25(\mathrm{OH}) \mathrm{D}$ levels in men compared to women ${ }^{33}$. Nationwide, men are more likely than women to workout doors and may therefore have more sun exposure and higher serum 25(OH)D levels. In contrast, all doctors follow a similar work schedule that requires them to be indoors for the majority of day light hours.

Our study demonstrated that obesity was associated with vitamin D deficiency which was similar with previous studies ${ }^{34}$. In our study, the obese population demonstrated mean serum 25(OH)D levels that were significantly lower than the non-obese population. The association between 25(OH)D levels and obesity may be because of lower vitamin D bioavailability of obese people from cutaneous and dietary sources as vitamin $\mathrm{D}$ has a tendency to deposit in adipose tissue ${ }^{34}$. In obese subjects, the increase in blood vitamin D concentration sis smaller than in non-obese individuals after an oral dose of vitamin D or following sunlight exposure.

Our study demonstrated that patients had higher physical activity levels (more than 30 minutes/day) were more likely to have higher $25(\mathrm{OH}) \mathrm{D}$ concentrations and lower percentages of vitamin $\mathrm{D}$ deficiency $(\mathrm{P}$ $<0.05$ ). We also observed that the participants who had a history of sufficient sunlight exposure had significantly less vitamin D Deficiency which is very much expected and supported by many other studies $^{33-35}$.

One of the major determinants of serum 25(OH)D level in our study was supplemental vitamin $\mathrm{D}$, in agreement with previous observations ${ }^{33}$. In our study, the majority of physicians with a sufficient serum 25(OH)D level were either taking vitamin D supplements or had higher exposure to sunlight or both. In our study among the participants who received vitamin D supplements (e"400 IU daily) more than 22\% had sufficient vitamin D label and around 5\% of those who has no such history. Although, most of the participants despite having history of vitamin D supplementation did not achieve the goal for vitamin D sufficiency. A recent Indian study showed that cholecalciferol of 60000 IU sachet once a month in summer maintains the desired concentration of vitamin $\mathrm{D}$ in subjects with hypovitaminosis $\mathrm{D}^{34}$. The present study is one of the few studies carried out to evaluate the status of vitamin $\mathrm{D}$ in the medical community in Bangladesh.

The limitations of our study are that we did not measure serum levels of parathyroid hormone which would be expected to be high at such low serum levels of vitamin D. Also, we did not evaluate Serum calcium level or vitamin D intake, circumstances of physical activity (indoor or outdoor), and extent of body surface exposed to sunlight.

\section{Conclusions}

In conclusion, vitamin $\mathrm{D}$ deficiency is very common $(65.8 \%$ with25(OH)D $<20 \mathrm{ng} / \mathrm{mL}$ ) among physicians of all over Bangladesh and is largely attributed to Age, obesity, sunlight exposure, physical inactivity, hypertension and vitamin D supplementation. Vitamin $\mathrm{D}$ deficiency reaches its highest expression not only in vulnerable groups like children, the elderly, and pregnant women but also in health care professionals. The high prevalence of vitamin D deficiency in the present study points towards urgent need of an integrated approach to detect vitamin D deficiency among health care professionals and treat appropriately.

Conflict of Interests: This is to certify that the Investigators do not have any matters which might give rise to a real or perceived conflict of interest. There is no existence of any personal interest, pressure of biasness and involvement with any organization which can mislead during the study procedure.

Funding: The study was supported by the unconditional unrestricted educational grant from Beximco Pharmaceuticals Ltd. 


\section{References}

1. Van Schoor, N.M.; Lips, P. Worldwide Vitamin D Status. Best Pract. Res. Clin. Endocrinol. Metab. 2011, 25, 671680. https://doi.org/10.1016/j.beem.2011.06.007. PMid:21872807

2. Mithal, A.; Wahl, D.A.; Bonjour, J.P.; Burckhardt, P.; Dawson-Hughes, B.; Eisman, J.A.; El-Hajj Fuleihan, G.; Josse, R.G.; Lips, P.; Morales-Torres, J.; et al. Global vitamin $\mathrm{D}$ status and determinants of hypovitaminosis D. Osteoporos Int. 2009, 20, 1807-1820.https:// doi.org/10.1007/s00198-009-0954-6.PMid:19543765

3. Van der Meer, I.M.; Middelkoop, B.J.; Boeke, A.J.; Lips, P. Prevalence of vitamin D deficiency among Turkish, Moroccan, Indian and sub-Sahara African populations in Europe and their countries of origin: An overview. Osteoporos. Int. 2011, 22, 1009-1021.https://doi.org/ 10.1007/s00198-010-1279-1.PMid:20461360 PMCid:PMC3046351

4. Ganji V, Zhang X, Tangpricha V. Serum 25hydroxyvitamin D concentrations and prevalence estimates of hypovitaminosis D in the U.S. population based on assay-adjusted data. J Nutr. 2012; 142(3):498-507. [PubMed: 22323766] https://doi.org/ 10.3945/jn.111.151977.PMid:22323766

5. Greene-Finestone LS, Berger C, de Groh M, et al. 25Hydroxyvitamin D in Canadian adults: biological, environmental, and behavioral correlates. Osteoporos Int. 2011; 22(5):1389-1399. [PubMed: 20730415.https://doi.org/10.1007/s00198-0101362-7 PMid:20730415 PMCid:PMC5102696

6. Gonzalez-Gross M, Valtuena J, Breidenassel C, et al. Vitamin D status among adolescents in Europe: The Healthy Lifestyle in Europe by Nutrition in Adolescence study. Br J Nutr. 2012; 107(5):755-764. [PubMed: 21846429] https://doi.org/10.1017/ S0007114511003527PMid:21846429

7. van Schoor NM, Lips P. Worldwide vitamin D status. Best Pract Res ClinEndocrinolMetab. 2011; 25(4):671680. [PubMed: 21872807] https://doi.org/10.1016/ j.beem.2011.06.007PMid:21872807

8. Binkley N, Krueger D, Cowgill CS, et al. Assay variation confounds the diagnosis of hypovitaminosis D: a call for standardization. J ClinEndocrinolMetab. 2004; 89(7):3152-3157. [PubMed: 15240586] https:// doi.org/10.1210/jc.2003-031979.PMid:15240586

9. Singh RJ, Taylor RL, Reddy GS, Grebe SK. C-3 epimers can account for a significant proportion of total circulating 25-hydroxyvitamin D in infants, complicating accurate measurement and interpretation of vitamin D status. J ClinEndocrinolMetab. 2006; 91(8):3055-3061. [PubMed: 16720650] https:// doi.org/10.1210/jc.2006-0710.PMid:16720650

10. Arya V, Bhambri R, Godbole MM, MithalA.Vitamin D status and its relationship with bone mineral density in healthy Asian Indians. OsteoporsisInt 2004; 15(1): 56-61.https://doi.org/10.1007/s00198-003-14913.PMid: 13680103

11. Islam MZ, Akhtaruzzaman M, Lamberg-Allardt C (2006) Hypovitaminosis D is common in both veiled and nonveiled Bangladeshi women. Asia Pac J ClinNutr 15:81-87.

12. Islam $\mathrm{MZ}$, Lamberg-Allardt $\mathrm{C}$, Karkkainen $\mathrm{M}$, et al. (2002) Vitamin D deficiency: a concern in premenopausal Bangladeshi women of two socioeconomic groups in rural and urban region. Eur $\mathrm{J}$ ClinNutr 56:51-56.https://doi.org/10.1038/ sj.ejcn.1601284. PMid:11840180

13. Bischoff-Ferrari HA, Dietrich T, Orav EJ, DawsonHughes B (2004) Positive association between 25hydroxy vitamin D levels and bone mineral density: a population-based study of younger and older adults. Am J Med 116:634-9. PMID: $15093761 \mathrm{https://}$ doi.org/ $10.1016 /$ j.amjmed.2003.12.029. PMid:15093761

14. Chapuy MC, Arlot ME, Duboeuf F, Brun J, Crouzet B, Arnaud S, et al. (1992) Vitamin D3 and calcium to prevent hip fractures in the elderly women. N Engl $\mathrm{J}$ Med 327:1637-42. PMID: 1331788https://doi.org/ 10.1056/NEJM199212033272305.PMid:1331788

15. Bischoff-Ferrari HA, Dietrich T, Orav EJ, Hu FB, Zhang Y, Karlson EW, et al. (2004) Higher 25-hydroxyvitamin D concentrations are associated with better lowerextremity function in both active and inactive persons aged 60 y. Am J ClinNutr 80:752-8. PMID: 15321818 https://doi.org/10.1093/ajcn/80.3.752.PMid: 15321818

16. Kremer R, Campbell PP, Reinhardt T, Gilsanz V (2009) Vitamin D status and its relationship to body fat, final height, and peak bone mass in young women. J ClinEndocrinolMetab 94:67-73. doi: 10.1210/jc. 20081575 PMID: 18984659 https://doi.org/10.1210/ jc.2008-1575 PMCid:PMC2630864

17. Hannan MT, Litman HJ, Araujo AB, McLennan CE, McLean RR, McKinlay JB, et al. (2008) Serum 25hydroxyvitamin $\mathrm{D}$ and bone mineral density in a racially and ethnically diverse group of men. J ClinEndocrinolMetab 93:40-6.https://doi.org/ 10.1210/jc.2007-1217 PMid:17986641 PMCid: PMC2 190744

18. DeLuca HF (2004) Overview of general physiologic features and functions of vitamin D. Am J ClinNutr 80:1689S-96S.https://doi.org/10.1093/ajcn / 80.6.1689S.PMid:15585789

19. Haussler MR, Haussler CA, Bartik L, Whitfield GK, Hsieh JC, Slater S, et al. (2008) Vitamin D receptor: molecular signaling and actions of nutritional ligands in disease prevention. Nutr Rev 66: S98-S112. https:/ /doi.org/10.1111/j.1753-4887.2008.00093.x. PMid: 18844852 
20. Davis CD, Dwyer JT (2007) The "sunshine vitamin"; benefits beyond bone? J Natl Cancer Inst 99:1563-5. PMID: 17971523.https://doi.org/10.1093/jnci/ $\operatorname{djm} 211$

21. Pittas AG, Harris SS, Stark PC, Dawson-Hughes B (2007) The effects of calcium and vitamin D supplementation on blood glucose and markers of inflammation in nondiabetic adults. Diabetes Care 30:980-6. https://doi.org/10.2337/dc06-1994. PMid: 17277040

22. Choi HS, Kim KA, Lim CY, Rhee SY, Hwang YC, Kim $\mathrm{KM}$, et al. (2011) Low serum vitamin D is associated with high risk of diabetes in Korean adults. J Nutr 141:1524-8. https://doi.org/10.3945/jn.111.139121. PMid:2 1697301

23. Lu L, Yu Z, Pan A, Hu FB, Franco OH, Li H, et al. (2009) Plasma 25-hydroxyvitamin D concentration and metabolic syndrome among middle-aged and elderly Chinese individuals. Diabetes Care 32:1278-83. https:/ /doi.org/10.2337/dc09-0209.PMid:19366976 PMCid:PMC2699709

24. Nimitphong H, Chailurkit L, Chanprasertyothin S, Sritara P, Ongphiphadhanakul B (2013) The association of vitamin D status and fasting glucose according to body fat mass in young healthy Thais. BMC Endocrine Disorders 13:60.https://doi.org/10.1186/1472-682313-60.PMid:24369921 PMCid:PMC3996198

25. Alvarez JA, Ashraf A (2010) Role of vitamin D in insulin secretion and insulin sensitivity for glucose homeostasis. Int J Endocrinol 351385.https:/ / doi.org/ 10.1155/2010/351385.PMid:20011094 PMCid: PMC2778451

26. Wang TJ, Pencina MJ, Booth SL, Jacques PF, Ingelsson E, Lanier K, et al. (2008) Vitamin D deficiency and risk of cardiovascular disease. Circulation 117:503-11. https:// doi.org/10.1161/CIRCULATIONAHA. 107.706127.PMid:18180395 PMCid:PMC2726624

27. Creo AL, Rosen JS, Ariza AJ, Hidaka KM, Binns HJ (2013) Vitamin D levels, insulin resistance, and cardiovascular risks in very young obese children. J PediatrEndocr Met 26:97-104.https://doi.org/ 10.1515/jpem-2012-0244.PMid:23382301
28. Holick MF, Binkley NC, Bischoff-Ferrari HA, Gordon CM, Hanley DA, Heaney RP, et al. Evaluation, Treatment, and Prevention of Vitamin D Deficiency: An Endocrine Society Clinical Practice Guideline. J ClinEndocrinolMetab. 2011; 96(7):1911-30.https:// doi.org/10.1210/jc.2011-0385.PMid:21646368

29. Islam SS, Mollah MAG, Rahman MM, Reza MA, Hossen M, Rahman MW, Alam MJ, Islam S, Evaluation of Vitamin D status among Doctors of a specialized hospital in Bangladesh. JBOS 2016; 31(2):80-84.

30. Singh SK, Prakash V, Tiwari S, Daliparthy DP, Singh $\mathrm{S}$, Jain P. Summer and winter prevalence of vitamin D deficiency of young resident doctors in North India. Nutrit Diet 2011; 68:280-4https://doi.org/10.2146/ news 110006.PMid:21289318

31. Mahdy SM, Al-Emadi SA, Khanjar IA, et al. Vitamin D status in health care professionals in Qatar. Saudi Med J 2010; 31:74-7

32. A1-Elq AH. The status of vitamin D in medical students in the preclerkship years of a Saudi medical school. J Fam Community Med. 2012;19(2):100-4. https:// doi.org/10.4103/2230-8229.98293 https://doi.org/ $10.4103 / 2230-8229.98293$. PMid:22870413 PMCid:PMC3410172

33. Premaor MO, Paludo P, Manica D et al. Hypovitaminosis $\mathrm{D}$ and secondary hyperparathyroidism in resident physicians of a general hospital in southern Brazil. J Endocrinol Invest 2008; 31: 991-5. https://doi.org/ 10.1007/BF03345637,\. PMid:19169055

34. Lips P, Duong T, Oleksik A, Black D, Cummings S, Cox $\mathrm{D}$, et al. A global study of vitamin D status and parathyroid function in postmenopausal women with osteoporosis: baseline data from the multiple outcomes of raloxifene evaluation clinical trial. $J$ ClinEndocrinolMetab 2001; 86:1212-21.https:// doi.org/10.1210/jcem.86.3.7327,PMid:11238511

35. Malhotra N, Mithal A, Gupta S, Shukla M, Godbole M. Effect of vitamin D supplementation on bone health parameters of healthy young Indian women. Arch Osteoporos 2009; 4: 47-53. https://doi.org/10.1007/ s11657-009-0026-8 PMid:20234858,PMCid:PM C2836750. 